\title{
The Evolving Jurisprudence of the International Administrative Tribunals: Convergence or Divergence?
}

\author{
Joan S. Powers*
}

\begin{abstract}
Between the late 1940s and 1980, there were two principal international administrative tribunals in operation - the United Nations Administrative Tribunal and the Administrative Tribunal of the International Labor Organisation. Observers at the time noted that certain principles of international administrative law had become wellestablished in the jurisprudence of these tribunals, and that their judgments reflected a commonality in approach. However, since 1980, a number of new administrative tribunals have been established by various international organizations, including each of the multilateral development banks and other international financial institutions, and the UN has changed to a two-tier judicial system. Now, with over 15 administrative tribunals in operation, can it still be said that there is a general harmonization amongst the tribunals? Or have the tribunals gone in different directions in analyzing the legal framework for the employment relationship within an international organization? This presentation will examine these questions with respect to selected issues considered by administrative tribunals.
\end{abstract}

\section{Introduction}

One thing that the diverse array of international and regional intergovernmental organizations have in common is that they provide staff with recourse to an independent administrative tribunal as part of their internal justice system. These tribunals are authorized to adjudicate employment disputes and render final and binding judgments, including remedial measures.

* Joan Powers, formerly Assistant General Counsel of the International Monetary Fund, is currently a consultant to various international organizations on employment-related issues and internal dispute resolution. She may be contacted at: joanspowers@yahoo.com. 
In the years between the late 1940 and 1980 , there were essentially two major international administrative tribunals in operation-the United Nations Administrative Tribunal (UNAT) serving the UN family of organizations, and the Administrative Tribunal of the International Labor Organisation (ILOAT) serving the ILO and other, mainly European-based, organizations that had accepted its jurisdiction. Contemporary observers at the time spoke of a "common system of law" between the international organizations, ${ }^{1}$ and noted that the tribunals applied the same general principles of law and also quoted each other's judgments, cautioning that "the consequences would be very awkward if it were otherwise". ${ }^{2}$

Since 1980, a number of new international administrative tribunals have been established, and there are now over 15 different administrative tribunals in existence. ${ }^{3}$ Given these developments, can it still be said that their respective case law and the principles they apply are consistent? Or have the various tribunals gone in different directions, with divergent views on the principles underlying the employment relationship in international organizations? This is a particularly important issue for newly established organizations like the Asian Infrastructure Investment Bank, which have to consider how best to structure their internal justice system and decide what would be the optimal approach.

\section{Background}

With respect to the administrative tribunals in operation prior to 1980 , the ILOAT is the oldest administrative tribunal, having succeeded to the

1 As of the 196os, scholars such as Prof. Michael Barton Akehurst referred to the "theory of a common system of law" between the international organizations, which was reflected in the tribunals' jurisprudence. M B Akehurst, The Law Governing Employment in International Organisations (CUP 1967) 262.

2 The source of these general principles is, however, somewhat murky. According to one leading commentator, " $[t]$ here is very little evidence of how general principles are identified in the judgments of these tribunals, though there are frequent references to such principles, and such principles are in fact often applied." C F Amerasinghe, The Law of the International Civil Service, vol I (2nd edn, Clarendon Press 1994) 158, n 46. See generally Renuka Dhinakaran, "Law of the International Civil Service: A Venture into Legal Theory" (2011) 8 International Organizations Law Review 137, 137.

3 AfDBAT; ADBAT; Bisat; CoE AT; EBRDAT; Eumetsat Appeals Board; esa Appeals Board; ESMAT; IDBAT; ILOAT; IMFAT; NATO AT; OASAT; OECDAT; UNAppT; WBAT. The European Union Civil Service Tribunal was dissolved in 2016. 
Administrative Tribunal of the League of Nations in the late $1940 .^{4}$ According to the ILOAT's website, it is currently open to more than 58,000 international civil servants who are current or former officials of 62 international organizations. The ILOAT has issued over 3,80o judgments since 1947.

The UNAT was established in 1950, and its jurisdiction was extended to various UN specialized agencies and other organizations that accepted its jurisdiction. ${ }^{5}$ Over the next 30 years, a few other international agencies established their own tribunals, including the Organization for Economic Cooperation and Development (1950), the Council of Europe (1965) and the Organization of American States in 1971. The European Space Agency established its own Appeals Board in the 1970s.

But the largest number of cases during this period, and the relevant jurisprudence, arose mainly at the UNAT and the ILOAT. International law scholars observed that these tribunals recognized and applied general principles of international civil service law, although there was no formal basis for doing so. ${ }^{6}$

The convergence between the various tribunals was noted not only by scholars but also by the tribunals themselves. The World Bank Administrative Tribunal (WBAT), in its very first decision, the landmark de Merode case (1981), ${ }^{7}$ mentioned the tendency towards a certain rapprochement in the solutions provided by other administrative tribunals in comparable situations. Similarly,

4 The first administrative tribunal was established in 1927 by the League of Nations. When the League was dissolved in 1946, the League Tribunal was reconstituted, with minor modifications, by the International Labour Organisation and became the ILOAT. In 1949, the ILOAT statute was amended to enable other international intergovernmental organizations to use the tribunal, and a number of organizations headquartered in Europe have accepted its jurisdiction.

5 The International Civil Aviation Organization (ICAO), the International Court of Justice (ICJ), the International Maritime Organization (IMO), the International Seabed Authority (ISA), the World Meteorological Organization (WMO), and the International Tribunal for the Law of the Sea (ITLOS) all accepted the jurisdiction of the UNAT.

6 Cf Akehurst (n 1 ) 262-263. According to Prof. Akehurst, "[i]nternational administrative tribunals behave as if the internal laws of different organizations formed part of a single system of law"; he observed that the "[t]ribunals seem to regard unwritten sources as constituting a sort of international administrative law, of universal application, which supplements the internal law peculiar to each organization." He concluded that "general principles of law constitute a source of law common to those internal laws and to general international law, so that general international law may rely on some of the precedents established by international ATs, and vice versa."

7 De Merode and Others $v$ IBRD, WBAT Decision no 1 (1981), para 28, stating that the Tribunal was "free to take note of solutions worked out in sufficiently comparable conditions by other administrative tribunals, particularly those of the United Nations family," so that it can "take account both of the diversity of international organizations and the special character of the Bank without neglecting the tendency towards a certain rapprochement." 
Lindsey (1992), the first decision of the Asian Development Bank Administrative Tribunal (АDВAT), spoke of "a large measure of 'common' law of international organizations to which, according to the circumstances, the Tribunal will give due weight." 8

Others, however, were not so sanguine. ${ }^{9}$ As early as 1973 , concerns were expressed about the risks of conflicting jurisprudence if there were multiple tribunals serving international organizations. Judge Manfred Lachs of the International Court of Justice wrote at length about this, and urged the creation of a single tribunal for all international organizations. He was of the view that "the problem of uniformity [had] become of great importance."10 He felt that the best solution would be to merge the UNAT and the ILOAT into a single administrative tribunal, and urged this to the United Nations, which took up the issue. The feasibility of such a merger was studied in detail by both organizations, ${ }^{11}$ but, in Judge Lachs's words, "difficulties of a bureaucratic nature surfaced ..."

By 1988, Judge Lachs wrote, rather despondently: "it is surely regrettable that notwithstanding the warning I gave 15 years ago, so little progress has been made." He "remained convinced that the goal of creating one Administrative Tribunal for all International Organizations [was] both realistic and desirable, in view of the difficulties and inequities arising out of the existing state of affairs." ${ }^{2}$

Not only did Judge Lachs's hopes for a single, world-wide tribunal never materialize, but also, starting around 1980, new administrative tribunals were

8 Lindsey $v A D B$, ADBAT Decision no 1 (1992), para 4. Lindsey also made reference to the role and importance of precedent and referred to "the staff practices of international organizations generally, including the decisions of international administrative tribunals dealing with comparable situations. There is, in this sphere, a large measure of 'common' law of international organizations to which, according to the circumstances, the Tribunal will give due weight."

9 C Wilfred Jenks, The Proper Law of International Organisations (Oceana Publications 1962) 41. In his 1962 study, Wilfred Jenks favored the creation of a single "World Administrative Tribunal" (his term) to serve all or most of the international organizations. But he also recognized that "the existence of more than one tribunal will, at the present stage of development, prove to be a service rather than a disservice to the development of a satisfactory body of international administrative law."

10 Manfred Lachs, "The Judiciary and the International Civil Service," (1988) Law of Nations, Law of International Organizations, World's Economic Law, Liber Amirocorum honouring Ignaz Seidl-Hohenveldern 301, 307

11 Report of the Secretary-General, "Feasibility of Establishing a Single Administrative Tribunal" (1984) UN Doc A/C.5/39/7

12 See Lachs (n 10) 313 
created by each of the international financial institutions. ${ }^{13}$ NATO transformed its Appeals Board into an administrative tribunal in 2013, and the recentlycreated European Stability Mechanism established its own administrative tribunal in 2014.

In addition to these new tribunals, the UN introduced major reforms in its internal justice system in 2009. The UNAT was abolished and replaced by a two-tiered justice system, ${ }^{14}$ consisting of three Dispute Tribunals that would hear cases in the first instance and one Appeals Tribunal (UNAppT) to conduct an appellate-style review, as the final and binding stage. Notably, both staff members and the Secretary-General may appeal decisions of the Dispute Tribunals to the Appeals Tribunal. The UNAppT has also made clear that the case law of the former UNAT is not necessarily binding on it. ${ }^{15}$

There are now over 15 international administrative tribunals serving either multiple or single organizations under their respective statutes. Collectively, these tribunals have issued well over 7,500 judgments since the late 1940 .

A 2004 report of the International Law Association emphasized the need for consistency and coherence in case law, and the importance of uniform interpretation of identical or similar provisions. The report recommended a common review mechanism over tribunal judgments "in order to achieve the greatest possible consistency of jurisprudence in international administrative law."16 The report also recommended that the tribunals be encouraged to take account of each other's decisions in efforts to reduce the risk of incompatible case law.

13 During the next 25 years, administrative tribunals were established by each of the major international financial institutions: World Bank Group (1980), Inter-American Development Bank (1981), Bank for International Settlements (1987), Asian Development Bank (1991), International Monetary Fund (1992), African Development Bank (1997), and European Bank for Reconstruction and Development (2002).

14 Between its establishment in $195^{\circ}$ and its abolition in 2009, the UNAT issued 1,495 judgments. The UNAppT has issued nearly 800 judgments since 2010.

15 Obdeijn $v$ Secretary-General of the United Nations, Judgment no 2012-UNAT-201, para 30. The UNAppT deliberately departed from the jurisprudence of the UNAT, noting that "the jurisprudence of the former Administrative Tribunal, though of persuasive value, cannot be a binding precedent for the new Tribunals to follow." It thus reached the opposite conclusion as the UNAT as to whether the Administration was obligated to provide reasons for the non-renewal of a staff member's contract, and the Administration's refusal to do so shifted the burden of proof from the staff member to the organization.

16 'Accountability of International Organizations: Final Report' in International Law Association Report of the Seventy-first Conference" (Berlin 2004) (International Law Association, London 2004), 48. "International administrative tribunals should be encouraged to take account of each other's decisions in order to reduce the risk of incompatible case law." 
Is this happening? Do the tribunals take note of each other's jurisprudence, or are they operating in isolation - and even in divergent ways?

The practice of the tribunals in terms of citing cases from other tribunals varies widely. It is quite uncommon for the ILOAT or the former UNAT to cite other tribunals, perhaps because they each have their own extensive jurisprudence to draw on. ${ }^{17}$

This contrasts with the practice of the tribunals of the World Bank, IMF and $\mathrm{ADB}$, which do occasionally cite cases from other tribunals. In one commentator's view, "[w] hile this is no indication that one tribunal regards the decisions of other tribunals as binding, it is evidence ... that there may be certain general principles of law applicable within the internal legal systems of international organizations pertaining to the employment relationship which extend beyond the limits of the internal system of any one organization."18

In recognition of this, Article III of the IMFAT Statute calls upon the Tribunal to adhere to and apply generally recognized principles for judicial review of administrative acts. At the time the IMFAT was established, it was recognized that these principles had already been extensively elaborated in the case law of the international administrative tribunals, particularly with respect to review of decisions taken under discretionary authority. ${ }^{19}$ So the objective of harmonization was made part of the IMFAT's statutory mandate.

17 A Triblex search indicates that ILOAT has never cited a judgment of the WBAT, IMFAT or ADBAT (even though an ADBAT case was apparently invoked by one complainant), and has only referred to the UNAT on three occasions. The UNAppT has occasionally cited with approval ILOAT rulings concerning the standard of judicial review of classification decisions, but this is infrequent. In Fuentes, it stated that "we note and endorse, in principle, the jurisprudence of the Administrative Tribunal of the International Labour Organization (ILOAT)." Fuentes $v$ Secretary-General of the United Nations, Judgment no 2010-UNAT-105, para 26.

18 CF Amerasinghe $(\mathrm{n} 2) 18$

19 Commentary on the Statute of the Administrative Tribunal of the International Monetary Fund, commentary on Article III <https://www.imf.org/external/imfat/report. htm\#commentary_III> accessed 23 November 2017. Nevertheless, the official commentary on the Statute made clear that the reference to general principles should not be construed so as to derogate from the IMF's Articles of Agreement or the Statute. According to the official commentary, "the reference [in Art III] to general principles is not intended to introduce concepts that are inapplicable to, or inappropriate for, the Fund. With respect to the concern that the application of the principles enunciated by other administrative tribunals may have the unintended result of interfering with the responsibilities entrusted to the Executive Board, it should be noted that, to the extent that a tribunal's decision is dependent on the particular law of the organization in question (such as the precise language of a staff regulation), the decision would be regarded as specific to the organization in question and not part of the general principles of international administrative law." 
What about the consistency of the rulings issued by these $15^{+}$tribunalscan it still be said that there still a "common law" as regards the international civil service and "general" principles regarding the law of the international civil service?

This is a huge question that deserves a more comprehensive treatment, but it may be instructive to examine a few types of employment-related decisions that are regularly reviewed by administrative tribunals: (i) abolition of position; (ii) disciplinary decisions; and (iii) review of rules of general applicability, or so-called "regulatory decisions."

Abolition of Position

One area of convergence, in which the tribunals have remained largely in sync, is in the review of decisions terminating a staff member's employment due to redundancy or abolition of position. Each tribunal has recognized the discretionary nature of such decisions, as well as the limitations on that discretion. ${ }^{20}$ The relevant issues are fairly clear and consistent across the tribunals:

- Was there a valid business rationale for making the incumbent redundant (e.g., outsourcing, restructuring, new skills required) and not simply a pretext for discrimination or dealing with substandard performance?

- Were the applicable procedures followed, e.g., notice to affected staff?

- $\quad$ Did the organization make sufficient efforts to find alternative positions for staff who would otherwise lose their jobs?21

20 E.g., KV ITER Organization, ILOAT Judgment no 3770 (2017), Consideration 7: "According to firm precedent, a decision concerning the restructuring of an international organization's services, which leads to the abolition of a post, may be taken at the discretion of its executive head and is subject to only limited review by the Tribunal. The latter must therefore confine itself to ascertaining whether the decision was taken in accordance with the rules on competence, form or procedure, whether it involves a mistake of fact or of law, whether it constituted abuse of authority, whether it failed to take account of material facts, or whether it draws clearly mistaken conclusions from the evidence. The Tribunal may not, however, supplant an organization's view with its own [citations omitted]. Nevertheless, any decision to abolish a post must be based on objective grounds and its purpose may never be to remove a member of staff regarded as unwanted. Disguising such purposes as a restructuring measure would constitute abuse of authority." See also González Flavell v IBRD, WBAT Decision no 553 (2017); Pacheco v Secretary-General of the United Nations, Judgment no 2013-UNAT-281, para 22.

21 E.g., $P v$ WHO, ILOAT Judgment no 3755 (2017); DI $v$ IBRD, WBAT Decision no 533 (2016), para 126; Sachdev $v$ IMF, IMFAT Judgment no 2012-1 (observing that "the obligation of the organization to assist a redundant staff member in identifying opportunities for 
In these types of cases, there is clearly a commonality of approach between the various tribunals, and the principles and standards they have applied are now typically reflected in the staff rules on redundancy (e.g., the organization's obligation of job search assistance to a staff member whose position is abolished), so there is considerable consistency between the organizations' internal legal systems on this as well.

Review of Disciplinary Decisions

Again, in general terms, the same analytical framework seems to be widely accepted across the administrative tribunals. Basically, there are three possible grounds for legal challenges to disciplinary sanctions imposed on a staff member who has committed misconduct:

(i) Have the facts been established and do they amount to misconduct under the organization's standards of conduct?

(ii) Was the sanction provided for in the staff rules and not disproportionate to the offense?

(iii) Did the organization follow proper procedures and respect due process? Although the principles cited by the tribunals in these cases are broadly consistent, they may be applied somewhat differently. This may be due to the fact that the concept of "due process" is anything but self-evident, and by its nature will be very fact-specific in practice. So the tribunals have reached different conclusions even within their own jurisprudence as to whether staff members who were investigated for misconduct were given adequate due process, including the opportunity to defend themselves (the adequacy of the notice they received; whether the length of time taken for the investigation and disciplinary process was excessive, ${ }^{22}$ etc.).

reassignment, which is given expression in the Fund's internal law ..., is supported by generally recognized principles of international administrative law ...").

22 Compare S.G. G. $v$ WIPO, ILOAT Judgment no 2698 (2008) (organization did not conduct the investigation with "all due speed," and such unjustified delay warranted moral damages to complainant) with S. (no 8) v IAEA, ILOAT Judgment no 3831 (2017), Consideration 27 (holding that a 25 -month delay in the completion of the investigation was not unreasonable in the circumstances, given the factual complexity of the case and difficulties securing the availability of witnesses) and S.N.-S. $v$ FAO, ILOAT Judgment no 2773 (2009) (although the proceedings took almost four years in total, this was explained in part by the need to thoroughly check the validity of the charges and review the lengthy documentation involved). 
But there are perhaps two aspects of disciplinary cases where interesting differences exist between the tribunals, and no uniform practice exists:

(i) the standard of proof to be applied;

(ii) the rights of victims of misconduct, e.g., harassment or retaliation, who have reported such behavior and asked for an investigation of the perpetrator.

With respect to the standard of proof in misconduct cases, the ILOAT has held that, in order to justify dismissal as a disciplinary sanction, the organization must establish misconduct "beyond a reasonable doubt." 23 This is an extremely high standard (derived from criminal law in certain national legal systems). The difficulties it poses were apparent in ILOAT Judgment no 2786 (2009) [wHo].

In this case, a staff member had been dismissed for submitting several fraudulent medical claims for medical services to his family members. However, the ILOAT overturned the termination decision, stating that it was "for the Organization to establish that the [staff member] has knowingly made a false claim". With respect to the allegation that the staff member had fraudulently obtained reimbursement for surgery performed on his wife, the ILOAT found that the organization had not sufficiently established the misconduct alleged beyond a reasonable doubt-even though the hospital in question had confirmed that it had no record of the patient or the treatment for which the staff member had claimed reimbursement. In the Tribunal's view, this evidence was insufficient to overcome the staff member's "entitle[ment] to the benefit of the doubt" (Consideration 16).

It must be said, however, that in its most recent session, the ILOAT dismissed a number of appeals against disciplinary sanctions, and upheld the organization's decision. ${ }^{24}$ The Tribunal emphasized that the question was not whether the Tribunal was satisfied beyond a reasonable doubt, but rather whether, on the basis of the evidence, the primary trier of fact could have properly found guilt beyond a reasonable doubt. This distinction is perhaps a nuance, but it could be outcome-determinative, since-as ILOAT itself has acknowledgedreasonable minds can differ about the probative value of evidence. ${ }^{25}$

23 See Navarro $v$ WHO, ILOAT Judgment no 969 (1989), Consideration 16; see also I. L. $v$ WHO, ILOAT Judgment no $2699(2008)$ and I. U. $v$ FAO, ILOAT Judgment no 2849 (2009).

24 See generally W. (no 2) $v$ FAO, ILOAT Judgment no 3882 (2017); F. v CERN, ILOAT Judgment no 3875 (2017); K. $v$ WHO, ILOAT Judgment no 3872 (2017); L. v OPCW, ILOAT Judgment no $385^{2}(2017)$.

25 E.g., S. $v$ International Criminal Court, ILOAT Judgment no 3863 (2017), Consideration 11. 
In contrast, the UNAppT has explicitly rejected the ILOAT standard and instead adopted a test of "clear and convincing" evidence in misconduct cases. ${ }^{26}$ The World Bank, ADB and the AfDB Tribunals are in line with the UNAppT on this. ${ }^{27}$ The UNAppT will generally defer to the Dispute Tribunal's findings as to whether misconduct has been duly proven. The difference in the legal standard of proof between "beyond a reasonable doubt" and "clear and convincing" could be outcome-determinative in certain cases.

A related development is that the UNAppT now reviews decisions by the Dispute Tribunals, which may be challenged by management as well as staff. In disciplinary matters appealed by the Secretary-General, the Appeals Tribunal has shown a willingness to disagree with the Dispute Tribunal's legal conclusions and overturn its ruling, for example, as to whether a sanction was disproportionate and reinstate the Secretary-General's original decision. ${ }^{28}$ So the stakes have clearly shifted in a two-tier judicial framework, where management also has the ability to appeal the decisions of the Dispute Tribunals. ${ }^{29}$

With respect to the rights of victims who lodge complaints of harassment or retaliation, this is a relatively new issue for the tribunals, such that it cannot

$26 \quad$ Molariv Secretary-General of the United Nations, Judgment no 2011-UNAT-164, paras 1 and 3o. In contrast, the UN Appeals Tribunal has stated: "We will not follow [the ILOAT] in holding that the standard of proof in disciplinary cases is beyond a reasonable doubt. While it is correct that beyond a reasonable doubt is the standard at the ILOAT, this has never been the standard at the United Nations... . Disciplinary cases are not criminal... . But when termination might be the result, we should require sufficient proof. We hold that, when termination is a possible outcome, misconduct must be established by clear and convincing evidence. Clear and convincing proof requires more than a preponderance of the evidence but less than proof beyond a reasonable doubt—it means that the truth of the facts asserted is highly probable." [citation and footnotes omitted].

27 AfDBAT: "The standard of proof in proceedings such these is proof on a balance of probabilities. [citation omitted] The Bank does not have to establish the Applicant's guilt beyond all reasonable doubt. It is sufficient if the Bank can establish on a balance of probabilities that it had just cause to terminate the Applicant's employment." B.O. v AfDB, AfDBAT Judgment no 95 (2016), para 87. АDBAT: the standard for investigations is "preponderance of the evidence." Mr. "E" $v A D B$, ADBAT Decision no 103 (2014), para 53. WBAT: "higher than a mere balance of probabilities." Bauman $v$ IBRD, WBAT Decision no 532 (2016).

28 See Portillo Moya $v$ Secretary-General of the United Nations, Judgment no 2015-UNAT-523, para 23, in which the UNAppT reversed the UNDT's conclusion that sanction of termination was disproportionate, where the staff member had engaged in fraud and failed to meet standards required of her position, including safeguarding the quality of distributed food products.

29 See, e.g., Carrabregu $v$ Secretary-General of the United Nations, Judgment no 2014-UNAT485 (allowing Secretary-General's appeal and overturning UNDT's determination that staff member was eligible for conversion to a permanent appointment). 
be said that "general principles" have been established. ${ }^{30}$ For example, do complainants have the right:

- To see the investigative report, and challenge the statements of the witnesses?

- To be informed of outcome and the sanction, if any, imposed on the perpetrator?

- To appeal a finding of no harassment and a decision not to impose any sanctions?

The tribunals appear to be dealing with these issues on a case-by-case basis, and individual cases are expanding the concept of due process rights for complainants, in additional to the alleged perpetrators of misconduct.

In a 2014 decision, ${ }^{31}$ the UNAppT rejected an appeal by the Secretary-General after the Dispute Tribunal had ordered him to inform the victim of retaliation of the nature of the disciplinary measures imposed on the persons responsible for the retaliation. In making this order, the UNDT acknowledged that there was no legal provision requiring the Secretary-General to do so, but it concluded that it would be fair and reasonable to do so, as part of the Secretary-General's responsibility to provide justice for the victim, and the UNAppT agreed. ${ }^{32}$

30 The justiciability of claims brought by staff who have complained of harassment is, however, well-established. In McKinney (no 2) v IBRD, WBAT Decision no 194 (1998), the WBAT considered the Bank's arguments that allowing complaining staff members to secure administrative and Tribunal review of any investigation undertaken (or not undertaken) by the Bank would have a disruptive impact, and that " $[t]$ here is no obligation owed by the Bank to the complaining staff member ... to resolve his allegations in his favor or to otherwise conduct the investigation in a manner desired by that staff member." The WBAT acknowledged that there is no obligation on the Bank to adopt the course of action urged by a complaining staff member. But in the tribunal's view, "What the Applicant here seeks is not that, but rather review of the investigating official for conduct that is arbitrary or lacking in due process. Such review is appropriate and can properly take account of the needs of the investigating officer for flexibility, confidentiality and the like. There is no reason to believe that allowing such review will seriously impede the operations of the Bank." (para 13)

31 Rahman $v$ Secretary-General of the United Nations, Judgment no 2014-UNAT-453, in which the UNAppT agreed with the Dispute Tribunal that "the victim of retaliation is entitled to know whether justice was done to the perpetrators of the retaliation, and that it is fair and reasonable to require the Secretary-General to provide this information, regardless of whether or not there is any legal provision to that effect. As the UNDT held, it is the Secretary-General's responsibility to dispense justice for the victim." (see paras 42-44) See also Nwuke $v$ Secretary-General of the United Nations, Judgment no 2010-UNAT-099, in which the UNAppT overturned the UNDT's ruling that it could not review the Administration's decision not to conduct an investigation. The UNAppT held that, although staff members have no right to compel the Administration to conduct an investigation (unless 
The ILOAT has gone even further with respect to the due process rights of staff who make claims of harassment. It has held that the organization's duty to a person who makes a claim of harassment means that the claim must be investigated promptly and thoroughly, the facts be determined objectively, the law be applied correctly, and due process be observed. This has meant, in practice, that the organization's refusal to provide the complainant with a copy of the investigative report was a breach of the right to procedural fairness, resulting in the award of moral damages. ${ }^{33}$ Similarly, moral damages were awarded to a complainant of harassment because she was not given the opportunity to comment on statements given by her former supervisor and challenge them, if necessary by introducing evidence. ${ }^{34}$ The ILOAT has awarded considerable moral damages to complainants in situations where it concluded that the organization had mismanaged their harassment complaints. ${ }^{35}$

The WвAт has been more equivocal as to exactly what due process rights are owed to the accuser. In $D K V$ IBRD, WBAT Decision no $55^{2}$ (2017), a staff member who had complained of sexual harassment wanted the ethics office to reopen its investigation, which had concluded that there was no sexual harassment and that the complainant had engaged in a consensual relationship with the alleged perpetrator. The Bank took the position that under the Staff Rules, the complainant's only rights are to be generally informed of the outcome of the investigation, and that the information provided in this instance went beyond this minimal requirement. The швAт found that there had been valid reasons for the decision not to reinvestigate the allegations, and these reasons had been given to the complainant. But it pointed out that any investigative findings on allegations of sexual harassment may affect the rights of the complaining staff member as well as the suspect. It therefore encouraged the Bank "to consider whether in conducting such investigations it takes due account

such right is provided in Rules and Regulations), there is a duty to consider requests for investigation (paras 39-40), and the organization will be accountable on this.

33 In $S$. (no 8) $V$ IAEA, ILOAT Judgment no 3831 (2017), a staff member claimed that she had been the victim of harassment and requested an investigation. The investigation concluded that harassment had not occurred and closed the case; the organization refused to provide the complainant with a copy of the investigative report, on confidentiality grounds. She pursued the matter to the ILOAT. The tribunal, although acknowledging that the complainant did not have the same due process rights as a staff member who is suspected of misconduct, nevertheless held that the failure to provide her with a copy of the report was a breach of her right to procedural fairness, and awarded her moral damages.

34 See G. v EPo, ILOAT Judgment no 3617 (2016), Considerations 11 and 12.

35 See, e.g., S. F. d M. (nos 1 and 2) v ILO, ILOAT Judgment no 3777 (2017); E. v FAO, ILOAT Judgment no 3593 (2016). 
of the rights of the complaining staff member who claims to be the victim of sexual harassment." 36

In Ms. G (no 2), AD BAT Decision no 107 (2015), the Applicant claimed that her supervisor had harassed her, and she asked for an investigation, which was done. The investigators interviewed some but not all of the witnesses suggested by the Applicant. The investigation did not find harassment on the part of the supervisor, and the Tribunal did not disturb this finding. However, because the investigation did not interview all of the witnesses named by the Applicant, the Tribunal awarded her damages, at least in part for this reason, as she- the erstwhile victim - had "a right to a proper conduct of the investigation" under the staff rules (Administrative Order 2.04).

In short, the various tribunal pronouncements on the due process rights of both the accused and a complainant in harassment cases have created challenges for international organizations in balancing the interests of all the parties involved in such cases. It is fair to say that harassment and bullying are areas where organizations are struggling with different definitions and procedures, not only in drafting their investigative protocols, but also with respect to the relationship between the disciplinary process and other internal proceedings in which allegations of harassment play a role, which could occur, for example, in challenges to performance assessments or other types of careerrelated decisions.

All of the tribunals recognize, in one way or another, that decisions taken by the governing bodies of any organization that alter the terms and conditions of employment are subject to judicial review. Although the terminology may differ somewhat, each tribunal has recognized important limitations on this authority, on the basis of such concepts as "acquired rights" or "fundamental terms and conditions" of employment, as well as non-retroactivity and abuse of discretion. ${ }^{37}$ These concepts may not have identical meanings, but they

$36 \quad$ DKv IBRD, wBAt Decision no $55^{2}$ (2017), (para 163; emphasis added).

37 See generally Kaplan v. Secretary-General of the United Nations, Former UnAT Judgment no 19 (1953); Poulain d'Andecy v FAO, ILOAT Judgment no 51 (1960); Lindsey $v$ ITU, ILOAT Judgment no 61 (1963); Elsen and Elsen-Druout $v$ EPO, ILOAT Judgment no 368 (1979); de Merode et al $I B R D$, WBat Decision no 1 (1981); Pinto v IBRD, WBAt Decision no 56 (1988); von Stauffenberg $v$ IBRD, WBAT Decision no 38 ( 1987); Aicher $v$ OECD, OECD Appeals Board Decision no 37 (1964). 
underscore that the tribunals are prepared to review legislative decisions by the governing organs against higher legal norms.

But the ways in which the administrative tribunals go about reviewing decisions of general applicability have some interesting differences. How do staff go about challenging Board decisions? When is a decision of general applicability ripe for review? Since there are no "class actions" as such before administrative tribunals, does a ruling as to one staff member automatically apply to similarly situated staff, or must multiple cases be brought?

These issues are evident in several recent tribunal judgments.

The ILOAT handed down a series of rulings in 2017 concerning a decision by the European Patent Office (EPO) to eliminate the ceiling on employees' contributions to health insurance. ${ }^{38}$ The decision was taken by the EPo's Administrative Council in 2010, but it also provided that the ceiling would remain in place for three years, i.e., until 2014, at which point it would be lifted; thereafter, contributions - taken from salary or pensions - could then exceed the ceiling.

More than 1,000 EPO employees appealed this decision, some ultimately turning to the ILOAT. However, the Tribunal dismissed the complaints on receivability grounds. The Tribunal held that staff could not directly challenge a decision of general applicability, as it had no immediate and direct effect on them. This ruling was consistent with several prior decisions ${ }^{39}$ in which the Tribunal had held that a general decision that required further individual implementation could only be challenged by impugning an individual decision, such as a change in an individual's salary or pension. ${ }^{40}$

38 See M.R. (no 2) and B.J. (no 4) vEPO, ILOAT Judgment no 3812 (2017); H. (no 3 ) vEPO, ILOAT Judgment no 3810 (2017); see also A. (no 75) $v$ EPO, ILOAT Judgment no 3628 (2016).

39 E. A. et al $v$ EPO, ILOAT Judgment no 3291 (2014), Consideration 8. The ILOAT explained that "allowing a complaint against a general decision which does not directly and immediately affect the complainant but which may have a direct negative effect on her/ him in the future would cause an unreasonable restriction of the right of defense, as staff members would then have to impugn immediately all general decisions which may have any connection with their future interests, on the basis that a general decision which is not challenged within the established time becomes immune from challenge."

40 The wват has taken a similar line regarding challenges to decisions of general applicability. See BL v IBRD, WBAT Decision no 446 (2010), para 30: "Furthermore, along with other international administrative tribunals, the Tribunal has consistently held that a claim of non-observance of a staff member's contract of employment or terms of appointment must be directed not against the Organization's promulgation of some general rule or policy but rather against an application of that rule or policy-be it reflected in an action or an omission - that directly affects the employment rights of a staff member in an adverse manner. (Briscoe v IBRD, WBAT Decision no 118 [1992], para 30)." [emphasis added.] See generally Andronov $v$ Secretary-General of the United Nations, Former UNAT Judgment no 1157 (2003) (an "administrative decision" is a unilateral decision taken by the 
These complaints were dismissed in 2017-well after the changes at issue had gone into effect and had a financial impact on the complainants individually. The ILOAT pointed out that, when the complaints were initially filed, the ceiling had not been applied to the complainants individually and had not yet affected them. But now-some seven years after the Council decision they are challenging was taken - the complainants have had to go back through the internal appeals process and, essentially, begin anew. ${ }^{41}$

This contrasts sharply with the approach taken by the IMFAT, based on a specific provision in its Statute that was intended to avoid these difficulties. The drafting of this provision (Art VI(2)) was intentionally different than that of existing tribunals at the time, in three respects:

- First, a case challenging the legality of a general decision taken by the legislative organ (referred to as a "regulatory decision") may be brought directly before the Tribunal — no need to exhaust administrative remedies if gravamen of complaint is the legality of the policy itself, as Grievance Committee is not competent to review Executive Board decisions.

- $\quad$ Second, the provision allows for direct review within 90 days of the approval of a new policy - staff need not await application of the policy in an individual case, so long as there will be an adverse impact on them.

- Finally, under the direct review process, a finding of illegality has the effect of annulling the policy at issue, which means that the ruling would automatically apply to similarly-situated staff; no need for multiple applications or erstwhile class action to achieve this result. ${ }^{42}$

administration in a precise individual case, which produces direct legal consequences, and is distinguished from a decision having regulatory power).

41 Cf Perrin et al $v$ ADB, ADBAT Decision no 109 (2017) where, as permitted under the ADBAT's Statute, the Asian Development Bank and the applicants agreed to submit the dispute directly to the Tribunal without requiring recourse through prior administrative remedies. At issue was the legality of changes to the educational allowance and whether these changes abrogated fundamental conditions of employment. However, the Tribunal dismissed the case as inadmissible, on the grounds that "The Tribunal cannot review the alleged violation in accordance with the law in the absence of detailed facts and evidence as to the impact of the EA changes in relation to each Applicant under his or her employment contract." (para 59) The ruling left open the possibility that the applicants could bring a subsequent case in which they presented evidence of individual injury as a result of the impugned decision and the remedies sought.

42 Article XIV, Section 3 sets forth the consequences of a ruling in favor of an application directly challenging the legality of a regulatory decision. In that case, the statute provides for "annulment" of the decision, which means that it has no legal effect, and any prior applications of the decision would be null and void. 
These principles were incorporated in Articles VI(2) and XIV of the IMFAT Statute. ${ }^{43}$ In Daseking-Frank (IMFAT Judgment 2007-1), these provisions were used by staff to directly challenge a decision by the Executive Board introducing major revisions to the methodology for reviewing and adjusting the IMF's salary structure. These changes to the compensation system were systemic in nature, ${ }^{44}$ they had no immediate impact on actual salaries or even on the salary structure itself-this would require a separate decision in the context of an annual compensation review. But the direct review process allowed staff to challenge the first decision, that is, the systemic changes in the methodology for reviewing and adjusting the salary structure, directly before the IM FAT.

The IMFAT ultimately concluded that the changes did not infringe a fundamental element of employment, and it upheld the Executive Board's decision. But from a procedural standpoint, the direct review process allowed this issue to be decided relatively quickly; the outcome would automatically apply to all similarly-situated staff and not require individual complaints to be brought. Perhaps most importantly, it achieved the underlying intention of the Statute that a decision of general applicability may be challenged directly, without the need to await its implementation in individual cases. This allows for prompt resolution and avoids lingering uncertainty, which is particularly helpful when major changes are made to the employment framework.

In fact, the Statute of the African Development Bank Administrative Tribunal (Art. IV) goes so far as to authorize the Tribunal to issue advisory opinions upon request by the Board of Governors, presumably even before a regulatory decision is taken (although this provision has not been invoked to date).

\section{$6 \quad$ Observations and Conclusions}

It is undeniable that the various tribunals are distinct in the ways they consider and decide cases - even the style of their judgments is quite varied. And the

43 See Commentary on the Imfat Statute (n 19). The official Commentary to the IMFAT Statute on Art vi (2) explained that "[r] egulatory decisions could be challenged by adversely affected staff within three months of their announcement or effective date. It is considered useful to permit the direct review of regulatory decisions within this limited time period. As a result, the question of legality, and any related issues (such as interpretation or application) could hopefully be firmly resolved before there had been considerable reliance on, or implementation of, the contested decision."

44 Such revisions included changes to the cycle for conducting a market review vs. reliance on indexation; the composition of the relevant competitor markets and their weighting in the system; and the parameters of the discretion afforded to the Executive Board in deciding on the new salary structure. 
remedies provided, including the amounts and bases for the damages awarded, vary considerably.

But it has to be said that there is still far more convergence than divergence in the tribunals' jurisprudence. This is perhaps not surprising-particularly since the same tribunal judges often sit on more than one tribunal and bring their other experience with them. ${ }^{45}$ Moreover, the litigants will typically look for relevant case law to cite to a tribunal, even if it is from another tribunal. All of this reinforces the tendency towards commonality that is reflected in the case law. 46

But this begs the question whether such convergence is desirable or even appropriate. Does it make sense to aim for commonality in the employment frameworks of organizations as diverse as, say, the OAS and the European Molecular Biological Laboratory? On one hand, the administrative issues faced by international organizations are similar, and their internal staff rules have much in common. So, it seems sensible to try and harmonize the interpretation of that internal law by the various tribunals.

On the other hand, the emphasis on ensuring harmonization raises the question whether this may impede the organizations' ability to work out their own solutions, based on their own assessment of what is in the best interest of the organization. For example, the reliance on fixed-term appointments versus continuing or indefinite appointments varies greatly between international

45 David Ruzié, "L'influence des droits français sur celui de la fonction publique internationale et européene" [1995] L'Internationalité dans les Institutions et le Droit 199, 207, n 62. Prof. David Ruzié observed this tendency with approval, stating that it enables, "to a certain extent, a harmonization of the jurisprudence" notwithstanding differences in the internal laws of the different organizations.

46 Olufemi Elias (ed), The Development and Effectiveness of International Administrative Law on the Occasion of the Thirtieth Anniversary of the World Bank Administrative Tribunal (Martinus Nijhoff Publishers 2012) 325. Judge Chris de Cooker, a long-time observer of the international administrative tribunals, noted on the occasion of the 3oth anniversary of the швAт in 2011 that "managers, staff and judges refer more than ever to this system as a body of law." De Cooker commented that "since the 196o's, numerous books have been published on the law of international institutions and that of the international civil service. They all recognize the differences that do exist between the organizations in terms of objectives, purpose, size and rules, but also emphasize the fact that the organizations have much in common in terms of institutional law. Internal laws are very similar in most situations in most organizations, and so are the problems that they are facing. This communality is only increasing to the extent that today, easy reference is made by many to international administrative law, and to the international administrative law as a corpus juris." ibid, 320 . 
organizations. ${ }^{47}$ Whereas some organizations stress the need for continuity, others may want more flexibility and fewer constraints regarding non-renewal of fixed-term contracts, particularly in situations where the use of fixed-term contracts is intended to facilitate turnover and reflect fluctuations in the level and nature of projects as well as budgetary resources. Thus, a "one size fits all" approach in terms of the legal standards for review of non-extension of fixedterm appointments would be inappropriate.

Moreover, if each tribunal looks to the others as to what constitutes the highest or strictest level of due process, is that necessarily "best practice"? In particular, the requirement that harassment must be established beyond a reasonable doubt in order to justify termination of employment may be counterproductive to ensuring zero tolerance of unacceptable behavior in the workplace.

In conclusion, it may be useful from time to time to re-examine the longstanding assumption that international administrative law should be a cohesive body of law or corpus juris, if only to confirm its continuing importance and utility in protecting the employment rights of international civil servants, while providing sufficient flexibility to recognize distinctions in the internal law of international organizations.

47 Secretary-General Bulletin, "Continuing Appointment" (2011) UN Doc ST/sG B/2011/9. In 2011 the United Nations introduced new criteria and eligibility requirements for offering a continuing appointment, which will have the result of increasing the organization's reliance on fixed-term appointments. 